UDC 338.124.4

\title{
WORLD FINANCIAL CRISIS 2008-2009: CAUSES AND ECONOMIC IMPACT
}

\author{
Somchenko V.V., Sulieimanova A.N. \\ Zaporizhzhia National University \\ Ukraine, 69600, Zaporizhzhia, Zhukovsky str., 66 \\ vika-znu72@ukr.net, abcdf@znu.edu.ua

\section{ORCID 0000-0003-4860-0964}

Key words:

financial crisis, bankruptcy, unemployment, inflation, anti-crisis policy, mortgage lending, financial markets.
The article discusses the main causes, factors and consequences of the financial crisis of 2008-2009. The dynamics of the main macroeconomic indicators have been analyzed by comparing the data for previous and current periods. The role of mortgage lending, the destruction of the banking sector and the bankruptcy of USA investment banks have been highlighted. The methods and approaches used to overcome the economic crisis have been explored. Leading scientists and experts believe that the economic crisis of 2008-2009 was the largest in the United States since the Great Depression of 1920-1930. At the end of 2007, millions of Americans lost their jobs, many financial institutions and organizations collapsed, and billions of dollars saved in savings accounts were lost forever. Scientists say that the problem of the current housing market in the United States is at the heart of the global financial crisis. Since the beginning of 2008 , the crisis has grown globally and has begun to manifest itself in declining production volumes, falling demand and prices for resources and materials, rising unemployment and inflation. The USA authorities have taken various measures to address this issue. At the present stage, it is important to consider in detail the factors that influenced the emergence of the crisis and the consequences for the economic markets of all countries of the world in order to prevent the occurrence of a similar crisis in the future. The causes of the global crisis are diverse and difficult. The main reason for the emergence is the imperfect FED (Federal Reserve System) policy on overproduction of the USA dollar, which is considered the main world currency. The global financial crisis is a major event in recent years because it has its own features that differentiate it from the crises of the past.

\section{СВІТОВА ФІНАНСОВА КРИЗА 2008-2009 РОКІВ: ПРИЧИНИ ТА ЕКОНОМІЧНІ НАСЛІДКИ}

\section{Сьомченко В.В., Сулєйманова А.Н.}

Запорізький національний університет

Украӥна, 69600, м. Запоріжжя, вул. Жуковського, 66

\section{Ключові слова:}

фінансова криза, банкрутство, безробіття, інфляція, антикризова політика, іпотечне кредитування, фінансові ринки.
У статті розглянуто основні причини, фактори та наслідки фінансової кризи 2008-2009 pp. Проаналізовано динаміку основних макроекономічних показників, шляхом проведення порівняння даних за попередні і поточні періоди. Висвітлено роль іпотечного кредитування, руйнування банківського сектору та банкрутство інвестиційних банків США. Досліджено методи та підходи, що застосовуються для подолання економічної кризи. Провідні науковці та експерти вважають, що економічна криза 2008-2009 pp. була наймасштабнішою в США з часів Великої депресії 1920-1930рр. В кінці 2007 року мільйони американців втратили свої робочі місця, велика кількість фінансових установ та організацій зазнали краху, а мільярди доларів, що зберігалися на ощадних рахунках були назавжди втрачені. Вчені зазначають, що проблема на сучасному ринку житла в Сполучених Штатах лежать в основі глобальної фінансової кризи. 3 початку 2008 року криза набула світового масштабу і почала проявлятися у зниженні обсягів виробництва, зниженні попиту i цін на ресурси та матеріали, зростанні безробіття та інфляції. Органи влади США запроваджували різноманітні заходи для вирішення даної проблеми. На сучасному етапі, $\epsilon$ важливим детально розглянути чинники, які вплинули на появу кризи i наслідків для економічних ринків всіх країн світу для того, щоб перешкодити виникненню аналогічної кризи в майбутньому. Причини глобальної кризи різноманітні i непрості. До основної причини виникнення можна віднести не досконалу політику ФРС (Федеральної резервної системи), щодо перевиробництва долара США, який вважається основною світовою валютою. Світова фінансова криза є головною подією останніх років у зв'язку з тим, що має свої особливості, що відрізняють ії від криз минулих часів. 


\section{Statement of the problem}

In today's world, the economic crisis continues to be a serious problem for the world market. The financial crisis of 2008-2009 began in the United States and then affected most European countries. It was the result of a violation of the economic balance in the world. It is important to study the causes of the crisis and find solutions to countries out of crisis, which will create new measures to eliminate it.

\section{Analysis of recent studies and publications}

At the present stage, the financial crisis is one of the most serious socio-economic problems. This issue was given much attention by both domestic and foreign scientists: Mamchin M.M., Shamro Y.V., Hesin E.Yu., Kortunov S.V., Kovalev S.I., Pankov V.I. analyze national and international strategies for overcoming the crisis and predict the consequences of the crisis, the nature of the financial crisis which grew into a global economic downturn, [1], Bobrov E.A. considers and

\section{Objectives of the article}

The objective of the article is to study the causes of the financial crisis and its economic consequences, as well as an analysis of measures used to overcome crises

\section{The main material of the research}

The global financial crisis began in December 2007 and took the form of a deterioration in key economic components in most countries. The crisis began in the United States with failed mortgage lending, the crisis was greatly affected by the high liquidity of banks and financial institutions, which in turn led to a decrease in the market value of the largest companies in the international market. In turn, all this has led to a significant reduction in production, slowing economic growth in many countries with negative consequences.

The main reasons that caused the global crisis include:

1. The existence of high risk in the macroeconomic environment. Economic conditions in the United States

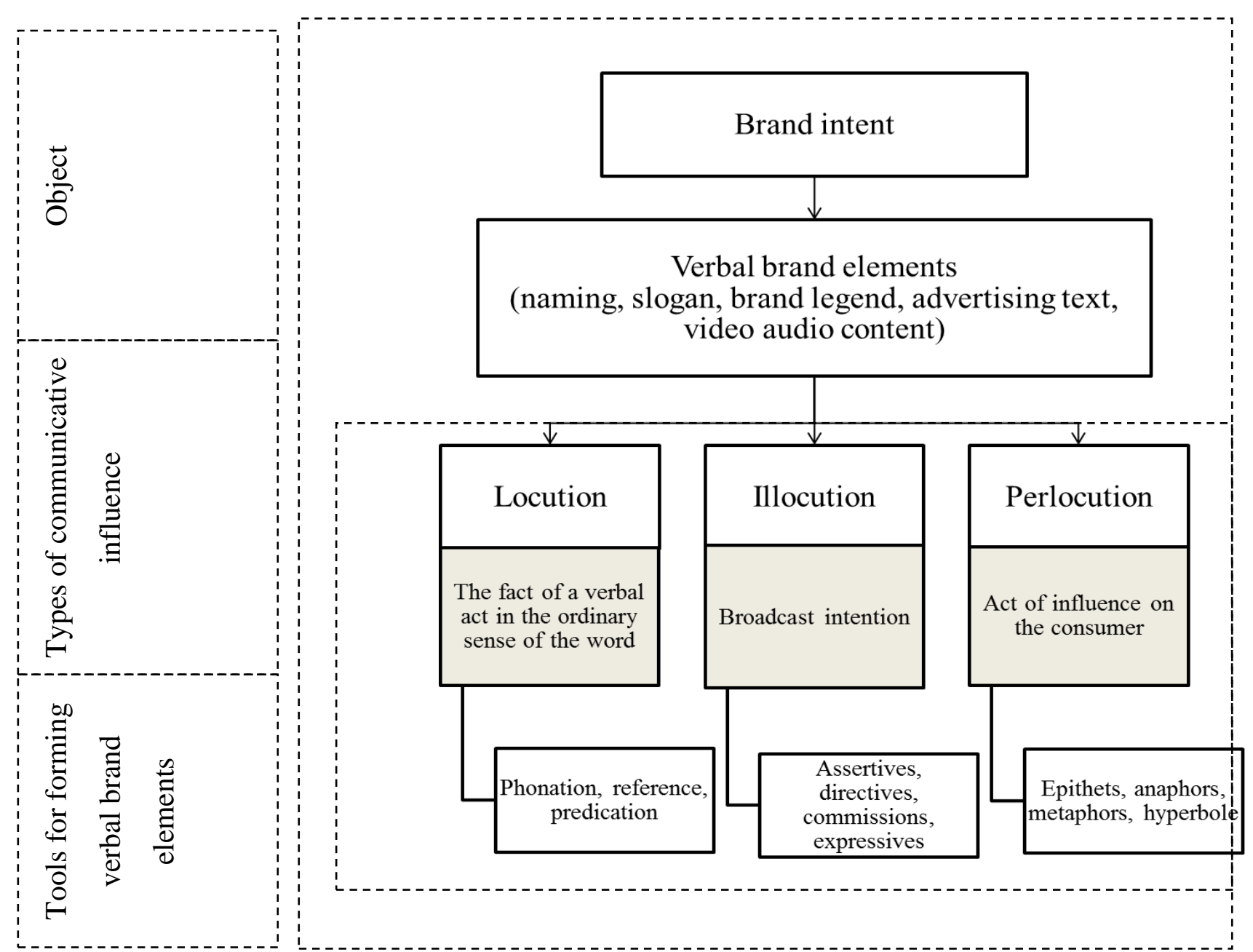

analyzes the main causes of the global financial crisis [2], Mamchin M.M., Shamro Y.V. analyze the components of the financial and economic system of developed countries and ways to overcome the crisis [3], Savchenko V.F., Kozlyanchenko O.M. in the work explore the experience and measures of different countries on the application of anti-crisis policy [4], Tyvonchuk I.O., Stetsyuk P.I., Tyvonchuk O.I. consider the factors that contribute to the crisis [5]. and elsewhere were favorable, and inflation and unemployment were relatively low. In most countries, housing prices were expected to rise, forcing people to take careless loans to buy and build houses.

2. Growth of borrowings from banks and investors. Banks and financial institutions borrowed money to buy assets to increase profits, but as a result, as housing prices began to fall, banks and investors suffered heavy losses. 
3. Imperfect credit regulation. As the crisis unfolded, many central banks, organizations, and governments did not fully recognize the extent of the spread of bad credit during the boom and the spread of mortgage losses through the economic system.
In 2004, the Federal Reserve (Fed) began raising rates, then $2.25 \%$. At the end of 2005 , it was $4.25 \%$, and in 2006 it was $5.25 \%$. These rates have risen much faster than in previous years. In 2007 the gradual reduction of the rate began and in 2008 it was the lowest indicators for all previous years of $0.25 \%$.

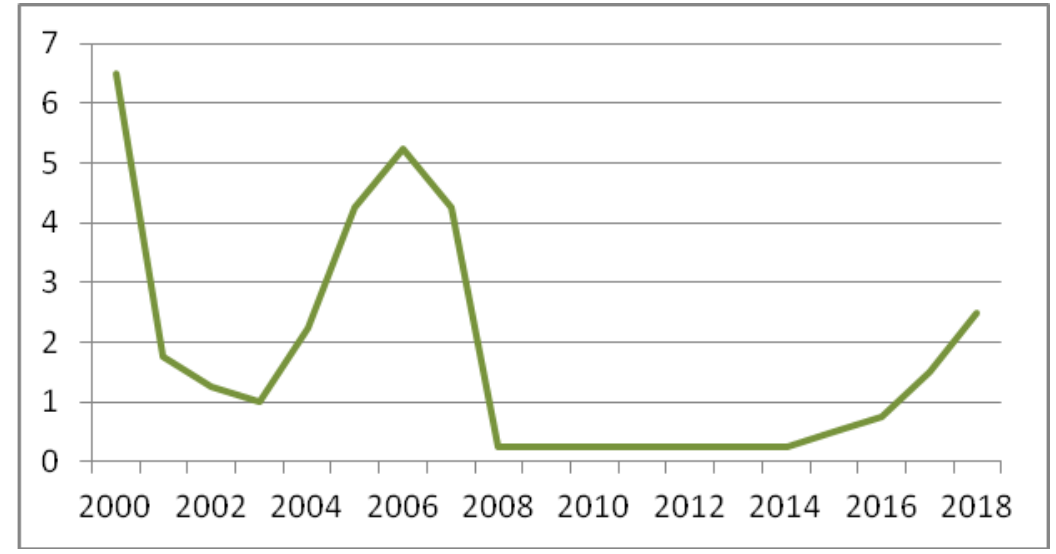

Fig. 1 Fed rate on the eve of the 2008 financial crisis

Source: compiled by the author based on [10]

Many banks in the world have suffered large losses and relied on government support to avoid bankruptcy. Millions of people lost their jobs when the world's major powerful economies experienced their worst recessions since the Great Depression.

The process of identifying a financial crisis involves, first of all, consideration of the factors that influenced its occurrence and its consequences. In most countries, such consequences are considered: a decrease in exports, lower real estate and stock prices, a significant reduction in lending, lower GDP [5].

Consequences of the global financial crisis for the United States:
- destruction of one of the most powerful banking systems in the world;

America's largest investment banks have ceased to exist, or Bear Stearns, Lehman Brothers, Merrill Lynch, Goldman Sachs and Morgan Stanley have been sold. Lehman Brothers was one of the largest investment banks in the world, which went bankrupt on September 15, 2008, which marked the beginning of the financial crisis. At that time, their debts amounted to about 788 billion dollars. The bankruptcy of this bank was one of the largest in American history. Morgan Stanley changed its line of business, ceasing to be an investment due to high risks, as well as to receive financial assistance from the state.

Table 1 - Bankruptcy of US banks

\begin{tabular}{|l|l|l|l|l|l|l|l|l|l|l|l|l|}
\hline Years & 2005 & 2006 & 2007 & 2008 & 2009 & 2010 & 2011 & 2012 & 2013 & 2014 & 2015 & 2016 \\
\hline Number & 0 & 0 & 3 & 30 & 140 & 157 & 94 & 57 & 26 & 22 & 8 & 4 \\
\hline
\end{tabular}

Source: developed by the author based on [11]

As we can see, in the United States before the global economic crisis, there were almost no bank failures, they began in 2008 and lasted almost 8 years.

- reduction of production;
According to the Department of Commerce, the volume of industrial orders in the United States in 2008 exceeded the forecast twice, this figure has fallen by more than $12 \%$ since last year, while it was expected to fall by $4 \%$ (Fig. 2).

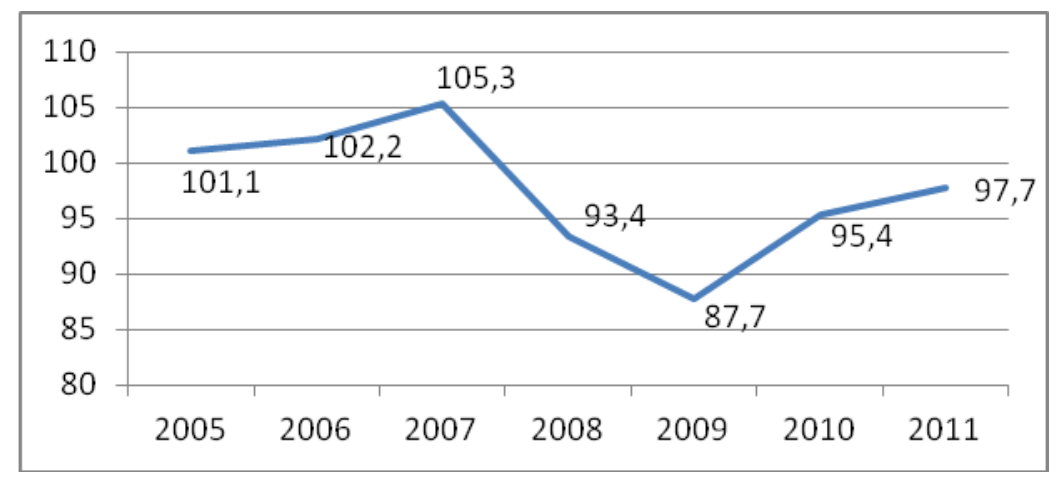

Fig. 2 Industrial production index

Source: compiled by the author based on [11] 
- high unemployment rate;

Overall unemployment in America remains extremely low. In the United States, only 3.8 percent of the workforce was unemployed in February 2019. Labor shortages and labor market shortages have also been reduced to a minimum. In the United States, this is due to the improvement of the employment program, which provides for the creation of new jobs. According to research by the Bureau of Labor Statistics, in 2010 the unemployment rate in the United States was $9.9 \%$, and in 2019 3.6\%. It can be concluded that over the last nine years, the unemployment rate has been slowly declining (Fig. 3).

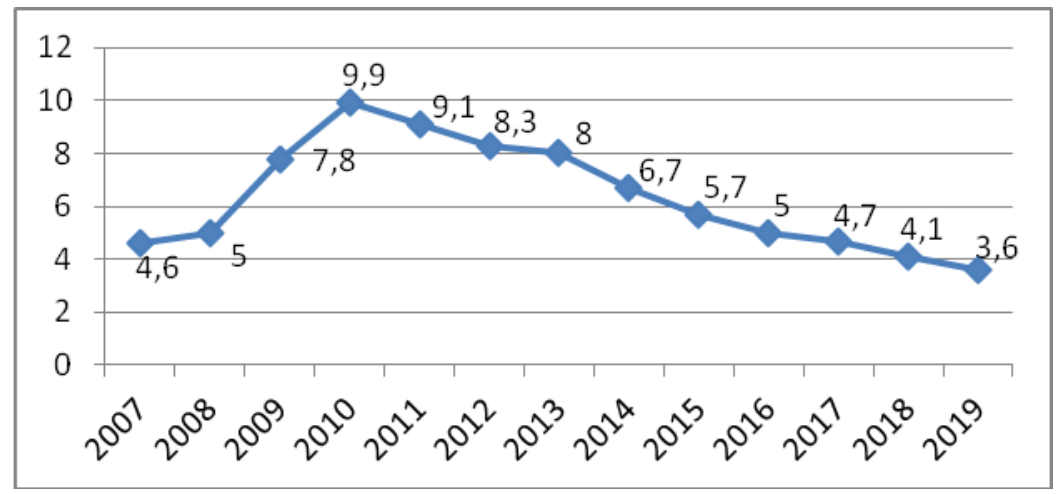

Fig. 3 Unemployment rate in the United States for the period 2007-2019

Source: compiled by the author based on [9]

Real average household income fell by $\$ 2122$, from $\$$ 59534 in 2007 to $\$ 57412$ in 2008 , the largest one-year

decline since 1967. From 2013, the average income gradually began to stabilize (Fig. 4).

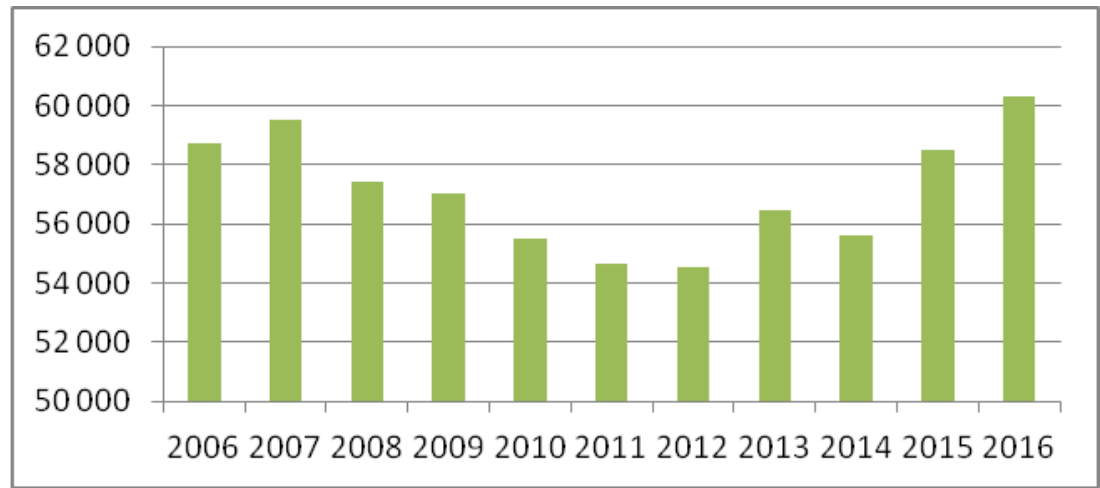

Fig. 4 Average household income in the United States for 2006-2016

Source: compiled by the author based on [13]

For the United States, 2007 ended in a government failure to fight rising prices. Record-breaking prices for decades have been observed in Europe, China, India and

Table 2 External debt of the US Treasury in 2008-2009 other Asian countries. Most of them were caused by the rapid rise in prices for agricultural products, oil and metals.

\begin{tabular}{|l|c|c|}
\hline \multirow{2}{*}{ Country } & December 2008 & December 2009 \\
\cline { 2 - 3 } & \multicolumn{2}{c|}{ (billion USD) } \\
\hline China & 727,4 & 894,8 \\
\hline Japan & 626,0 & 765,7 \\
\hline United Kingdom & 131,1 & 180,3 \\
\hline Banking centers in the Caribbean & 197,9 & 128,2 \\
\hline Oil exporters & 186,2 & 201,1 \\
\hline Brazil & 127,0 & 169,2 \\
\hline Luxembourg & 97,3 & 88,4 \\
\hline Russia & 116,4 & 141,8 \\
\hline Hong Kong & 77,2 & 148,7 \\
\hline Norway & 23,1 & 12,1 \\
\hline Switzerland & 62,3 & 89,7 \\
\hline Germany & 56,0 & \\
\hline Taiwan & 71,8 & 47,8 \\
\hline
\end{tabular}




\begin{tabular}{|l|c|c|}
\hline South Korea & 31,3 & 40,3 \\
\hline Mexico & 34,8 & 36,8 \\
\hline Turkey & 30,2 & 28,1 \\
\hline Singapore & 40,9 & 39,2 \\
\hline Thailand & 32,4 & 33,3 \\
\hline Ireland & 54,3 & 43,6 \\
\hline India & 29,2 & 32,5 \\
\hline Egypt & 17,2 & 18,9 \\
\hline Holland & 14,0 & 20,4 \\
\hline Chile & 8,5 & 12,4 \\
\hline Belgium & 15,9 & 17,3 \\
\hline Ireland & 54,3 & 43,6 \\
\hline Sweden & 12,7 & 15,2 \\
\hline Philippines & 11,7 & 11,7 \\
\hline Colombia & 11,2 & 17,3 \\
\hline Australia & 10,3 & 16,3 \\
\hline Italy & 16,0 & 21,1 \\
\hline Others & 252,2 & 292,4 \\
\hline Total & 3077,2 & 3685,1 \\
\hline
\end{tabular}

Source: developed by the author based on [2,8]

According to the United States Department of Labor, inflation in 2007 was $4.1 \%$, the highest in 17 years, and the lowest inflation rate was $0.1 \%$ in 2008 . Inflation has continued to fall since 2008 , due to a fall in the value of US Treasury bonds and a depreciation of the dollar (Fig. $5)$.

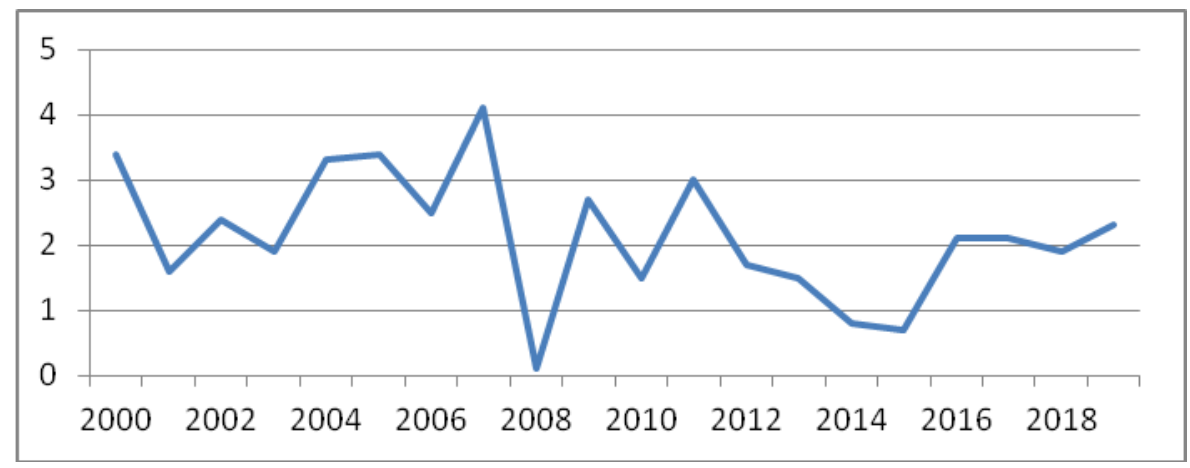

Fig. 5 Inflation rate in the United States 2000-2019

Implementation of anti-crisis measures will counteract the threats of the global financial and economic crisis, not only prevent its negative impact on the economy, but also overcome it, a stable and balanced economy provide economic growth, constant solutions to further improve living standards and welfare (Fig. 6) [4].

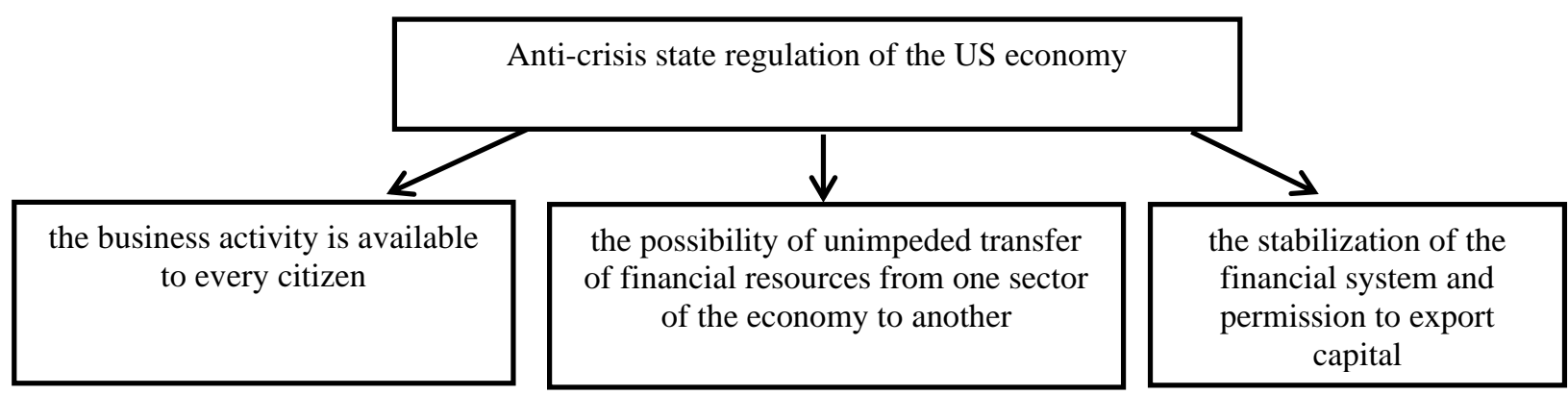

Fig. 6 Principles of anti-crisis state regulation of the US economy

The U.S. government has increased its spending to stimulate demand and support employment in the economy because nearly 6 million Americans have lost their jobs. To boost the confidence of financial institutions, the government has introduced guaranteed deposits and promissory notes, as well as acquired shares in some banks and financial firms, in order to prevent bankruptcies that could worsen the situation in the 124 financial markets. One of the most important changes in the banking sector has been that banks now need to assess the risk of lending more carefully and use more sustainable sources of funding.

\section{Conclusions}

Based on the analysis of the work done, the following conclusions can be drawn, the financial crisis of 20082009 caused huge devastating losses to the economy of 
the world, also affected a large number of people, losing their jobs and livelihoods. Signs of the global crisis of 2008 include the consumer lending in the United States, which led to higher prices for goods that reached the highest prices in the economic history of America. The duration of the financial crisis in many countries is partly due to the declining reliability of the economic system. Economic recovery also depends on consumer confidence, which contributes to the revival of costs and investment, a return to stable development in financial markets and the banking sector. Restoring confidence depends on the ability to properly combine the policies needed to address important issues and create a stable financial environment conducive to effective economic growth.

\section{References}

1. Hesin, E. Yu., \& Kortunov, S.V., \& Kovalev, S.I., \& Pankov, V.I. (2011). Zmina hlobalnoho ekonomichnoho landshaftu [Changing the global economic landscape], monograph, Moscow: Higher School of Economics, 396 [in Russian].

2. Bobrov, E.A. (2008). Analiz prychyn vynyknennya svitovoyi finansovoyi kryzy ta yiyi vplyv na ekonomiku Ukrayiny [Analysis of the causes of the global financial crisis and its impact on the Ukrainian economy]. Finance of Ukraine, 12, 43-44 [in Ukrainian].

3. Mamchin, M.M., \& Shamro, Yu.V. (2011). Osoblyvosti ta naslidky vplyvu svitovoyi finansovo-ekonomichnoyi kryzy na ekonomiku Ukrayiny. [Features and consequences of the impact of the global financial and economic crisis on the economy of Ukraine]. Kiev: Collection of scientific papers of the National University of the State Tax Service of Ukraine, 2, 171-179 [in Ukrainian].

4. Savchenko, V.F., \& Kozlyanchenko, O.M. Svitovyy dosvid antykryzovoho derzhavnoho rehulyuvannya [World experience of anti-crisis state regulation]. Chernihiv: Polesie Scientific Bulletin, 1 (5), 7-13 [in Ukrainian].

5. Tivonchuk, I.O., Stetsyuk, P.I., Tivonchuk, O.I. (2011). Finansovi kryzy: analiz prychyn ta mekhanizmiv yikh proyavu [Financial crises: an analysis of the causes and mechanisms of their manifestation]. Lviv: Bulletin of the National University "Lviv Polytechnic", 698, 112-118 [in Ukrainian].

6. Ministerstvo pratsi SSHA : riven inflyatsiyi 2000-2019 [USA Department of Labor: inflation rate 2000-2019]. Retrieved from https://www.dol.gov/general/topic/statistics/inflation (access April 4 2020) [in English].

7. Hlobalna finansova kryza [The global financial crisis]. Retrieved from https://www.rba.gov.au/education/resources/explainers/the-global-financial-crisis.html (access April 6 2020) [in English].

8. Kaznacheystvo Spoluchenykh Shtativ Ameryky [United States Treasury]. Retrieved from https://ticdata.treasury.gov/Publish/mfhhis01.txt (access April 9 2020) [in English].

9. Dykadyuk M. S. Kryza 2008 roku: 10 rokiv tomu rozpochalasya svitova finansova kryza [Dikadiuk, M.S. Crisis of 2008: 10 years ago the world financial crisis began]. Retrieved from https://gazeta.ua/articles/economics/_rozpochalas-svitova-finansova-krisa/859187 (access April 6 2020) [in Ukrainian].

10. Prychyny hlobal'noyi finansovoyi kryzy [The causes of the global financial crisis]. Retrieved from https://www.thebalance.com/what-caused-2008-global-financial-crisis-3306176\#citation-20 (access April 5 2020) [in English].

11. Istoriya bankivskykh zboyiv u SSHA [History of bank failures in the US]. Retrieved from https://www.davemanuel.com/history-of-bank-failures-in-the-united-states.php (access 13 April 2020) [in English].

12. Indeks promyslovoho vyrobnytstva Spoluchenykh Shtativ [United States Industrial Production Index]. Retrieved from https://www.investopedia.com/terms/i/ipi.asp (access April 14 2020) [in English].

13. Seredniy dokhid domohospodarstv [Average household income]. Retrieved from https://www.statista.com/statistics/200838/median-household-income-in-the-united-states/ (access April 14 2020) [in English]. 